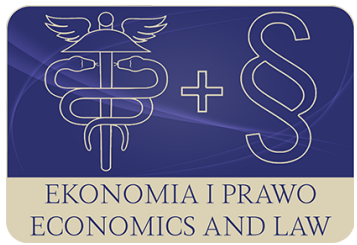

EKONOMIA I PRAWO. ECONOMICS AND LAW

Volume 20, Issue 2, June 2021

p-ISSN 1898-2255, e-ISSN 2392-1625

www.economicsandlaw.pl

ORIGINAL ARTICLE

received 23.05.2021; revised 20.06.2021; accepted 30.06.2021

Citation: Rosiński, R. (2021). The minimum wage in the national economy: reasons and changes

in Poland. Ekonomia i Prawo. Economics and Law, 20(2), 425-437. https://doi.org/10.12775/EiP.2021.026.

\title{
The minimum wage in the national economy: reasons and changes in Poland
}

\author{
RAFAE ROSIŃSKI \\ Koszalin University of Technology, Faculty of Economic Sciences, Department of Finance, \\ ul. Kwiatkowskiego 6e, 75-343 Koszalin, Poland \\ ๑ rafal.rosinski@tu.koszalin.pl \\ (D) orcid.org/0000-0002-9001-9922
}

\begin{abstract}
Motivation: The minimum wage protect employees from excessively low wages. It helps ensure fair participation in economic development for the general public. The minimum wage in the economy is an essential element in a country's economic policy. Decisions concerning the implementation and changes in the minimum wage are part of the socio-economic policy of the state. Research on minimum wage relate to its overall impact on the level and structure of wages, employment, productivity at work, the size of the gray economy, the level of poverty and public finances. Factors affecting changes in the minimum wage are formal and non-formal. The question therefore arises which factors are decisive in the Polish economy.

Aim: The aim of this paper is to present the essence and causes of changes in the minimum wage in Poland in 2003-2020 with particular regard to formal and non-formal aspects.

Results: On the basis of research carried out in Poland, a link between minimum wage and inflation was observed. There is also a fundamental relationship between the minimum wage and average wages in the economy. It has been shown that the minimum wage is not without significance for the impact on public finance sector in Poland.
\end{abstract}

Keywords: minimum wage; public finance; Polish economy

JEL: J30; J38; K31; G38; H60 


\section{Introduction}

The International Labour Organization defines the minimum wage as the minimum amount of remuneration that an employer is required to pay wage earners for the work performed during a given period, which cannot be reduced by collective agreement or an individual contract (ILO, 2016a, p. 3). Decisions concerning the implementation and changes in the minimum wage are part of the socio-economic policy of the state. Research on minimum wage relate to its overall impact on the level and structure of wages, employment, productivity at work, the size of the gray economy, the level of poverty and public finances. The purpose of the article is to present the essence and causes of changes in the minimum wage in Poland in 2003-2020. The subject of the research will be the reference to the change in the minimum wage to formal and non-formal aspects related to, among others with changes in inflation, GDP and public spending in Poland. The source of data is the data of the Central Statistical Office.

\section{Literature review}

\subsection{Purpose and formal aspects of the minimum wage}

The goal of the minimum wage is to protect employees from excessively low wages. It helps ensure fair participation in economic development for the general public. The minimum wage can also be part of the policy to overcome poverty and reduce inequalities, including between men and women. In addition, minimum wage systems should be defined and designed to complement and strengthen other social systems and employment policies, including collective bargaining, which are used to determine employment and working conditions (ILO, 2016b, p. 19).

Minimum wages are still at the heart of political debates in both developed and emerging economies. Such policies can only be effective if the existing regulatory system has no loopholes that allow the payment of wages below the minimum wage and existing minimum wage rules are not affected (Goraus-Tanska \& Lewandowski, 2016, p. 2). In countries with rapid GDP per capita growth, workers often demand raising the minimum wage. Economies struggling with in-work poverty or in the event of wage inequality are implementing a minimum wage policy.

In international terms, the Kaitz index (indicator) is used as a comparison criterion for the minimum wage. The Kaitz index is calculated as the relation between the minimum wage and the average wage in the national economy (Cahuc \& Zylberberg, 2004, p. 715).

The minimum wage is formally reflected in the regulations of the International Labor Organization (ILO). In Minimum wage fixing convention no. 131 (ILO, 
1970) contains regulations aimed at establishing a minimum wage system which will cover all groups of persons receiving remuneration whose employment conditions are such that it is justified to include them. The recommendation on determining the minimum wage states that the number and groups of people receiving remuneration that are not covered under Art. 1 of the Convention should be kept to a minimum. In the event that an ILO Member State ratifies Convention 131, the competent national authority may exclude certain groups of employed persons from the scope of its minimum wage system, in consultation with social partners. As a consequence, the minimum wage system established under Convention 131 does not necessarily have to cover all employees.

An analysis of the legal system of individual national economies shows that the most common groups excluded from the minimum wage systems are agricultural workers and domestic workers. Other groups often excluded include: family businesses, small businesses, trainees and disabled workers (ILO, 2020).

Convention 131 is supplemented by Domestic workers convention no. 189 (ILO, 2011), which clearly states that each country undertakes to take appropriate measures to ensure that domestic workers are covered by the minimum wage, if such protection exists, and that the remuneration will be determined without discrimination based on sex (ILO, 2011).

It should also be noted that specific regulations apply to the public sector. In many countries, public sector employees are excluded, in whole or in part, from labor law, including regulations regarding the setting of a minimum wage. However, this does not mean that the minimum wage does not apply to them, as they may be covered by regulations or administrative arrangements that often cover specific pay scales (pay ranges). Salary scales in the public sector are usually adjusted so that they are not lower than the minimum wage. One area of concern in this context is the impact that the increase in the minimum wage may have on public sector expenditure. The minimum wage can act as a wage multiplier in the public sector. In such cases, an increase in the minimum wage can have far-reaching consequences for public expenditure.

\subsection{Minimum wage and public expenditure}

Most political debates and economic literature on the minimum wage focuses on the effects of employment (Neumark \& Wascher, 2006), its impact on the level of other wages (Holtemöller \& Pohle, 2019), on income inequality (Autor et al., 2010), impact on wages because of their sex (Williams \& Mills, 1998, pp. 397-414), optimality of a minimum wage (Hungerbuhler \& Lehmann, 2009, pp. 464-481), poverty problems in developing countries (Saget, 2001, pp. 237-269) supporting poverty in developed countries (MaCurdy, 2015, pp. 497-545), enforcement and compliance with minimum wage rules (Goraus-Tanska \& Lewandowski, 2016), differentiated impact on economic development (Askenazy, 2003) or crime level (Braun, 2019, pp. 122-152). 
Research on the minimum wage covers many aspects, but it also has a significant impact on the level of public expenditure. The above situation can take two scenarios: the first scenario is related to the situation that when the minimum wage is raised, only the salary of employees receiving wages below the minimum increases, the second scenario is that pressure is automatically applied to the salaries of employees in other groups and there is also an increase salaries.

The minimum wage is also linked to the cost of social benefits, where it is often a specific point of reference to the amount of benefits paid. Such a link may occur, for example, with retirement benefits paid out, the increase of which may cause a gap (deficit) in the pension insurance system. These connections in individual countries may be different, i.e. related to, among others, benefits for employees whose salaries are indexed to the minimum wage, the amount of such benefits as: funeral allowances, childbirth allowances, sickness allowances, unemployment benefits, disability benefits, scholarships paid to participants of vocational training programs, salary bonuses, including "13. Salary", public works programs or tax exemptions.

In addition, the minimum wage is used in some countries as a criterion for participation in some social programs. Further relationships that may arise in connection with the increase in the minimum wage are as follows: if the minimum wage increases more than the average wage, the demand for social programs, such as housing benefits or food vouchers, will also increase. Indirectly, therefore, an increase in the minimum wage may increase expenditure on employment-related social programs. Higher minimum wages can lead to unemployment, especially among the poor, and therefore there will be a greater demand for programs to protect the income of the unemployed, such as public work, subsidized loans and unemployment insurance. In some countries (Chile), minimum "non-wage" minimum wages are also created, which are used for indexing only for social purposes. (Cunningham, 2007, pp. 59-63). Although a higher minimum wage can increase government spending, it can also create additional resources for the state budget. As outlined earlier, the minimum wage will have a positive effect on wages for a part of the population, so the additional income may come from higher taxes on work, which are a function of wages. Therefore, the impact on the state budget may be positive or negative, depending on the size and nature of social programs and fiscal efficiency of taxes. However, it is generally likely that increased government spending on people with low wages will outweigh the increase in tax collection due to the effect of overall wage increases. Thus, in connection with the above, there is a redistribution to the income of poor employees who experience the largest increase in wages and non-working recipients of public programs related to the value of the minimum wage (Cunningham, 2007, pp. 59-63).

To sum up, on the one hand, the minimum wage is one of the frequently used tools of socio-economic policy to reduce poverty and social justice, because it does not require significant government expenditure. On the other hand, however, an increase in the minimum wage can cause unintended side effects that 
affect public finances. There are three main links between the minimum wage and public finances. The first aspect is when a higher minimum wage can lead to an increase in wage expenditure in the public sector, especially in the public sector, where the wage level is calculated as a multiple of its minimum. In some cases, this direct link and fear of the consequences associated with it affects the decision to raise the minimum wage. The second case is the linking of the minimum wage with various aspects of social protection, such as pensions, invalidity pensions or maternity benefits. In practice, this means that expenses related to the payment of retirement benefits and other social expenses will automatically increase when the minimum wage increases. The third link shows the relationship in favor of the financial situation of the state and occurs where governments raise minimum wages to solve poverty problems and thereby reduce the amount of social transfers for low-paid employees (ILO,2016a, pp. 11-12).

These links can be attractive for a variety of reasons, but attention should be drawn to the fact that they pose a risk of potentially unsustainable social development if the minimum wage is raised unreasonably. If the minimum wage increases faster than the average wage to reduce wage disparities, the consequence is that social security expenditure increases faster than the income base of the social security system, which depends on trends in real earnings (Marinakis \& Velasco, 2006, pp. 11-12). Studies on the macroeconomic consequences of an increase in the minimum wage indicate that a moderate increase in the minimum wage hardly affects employment, but compresses the wage distribution and generates positive side effects at higher wages. In the case of a very large increase in the minimum wage, the consequences are already to the detriment of employment, i.e. it causes its decline (Bauducco \& Janiak, 2017, pp. 57-76). Lee (1999, pp. 977-1023) presented similar results in this respect earlier and Card \& Krueger (1994, pp. 772-793).

\section{Methods}

This paper features theoretical and empirical aspects and it presents a critical analysis of the scientific discourse concerning the minimum wage. Documents of international organizations such as the International Labour Organisation (for a different time horizon), data from the Central Statistic Office and Polish acts law were analyzed.

Study of the subject of the literature critical review was carried out and the secondary sources were used.

Statistical methods such as dynamics analysis and comparison analysis, including the Kaitz indicator, the Pearson correlation were used to analyze empirical data. 


\section{Results}

The minimum wage in Poland is regulated by the Act on the minimum wage for work (2002). The minimum wage is negotiated annually within the framework of the Council for Social Dialogue. The Council of Ministers, by 15 June each year, presents the Social Dialogue Council with a proposal for the minimum wage and hourly rate in the economy in the following year, taking into account specific economic conditions. The amount of the minimum hourly rate is adjusted annually by an indicator resulting from dividing the amount of the minimum wage set for the next year by the amount of the minimum wage in force in the year in which negotiations take place. In accordance with art. 3 of the Act, if the next price index forecast for the year is: at least $105 \%$ - two deadlines for changing the minimum wage and the minimum hourly rate are set: from January 1 and July 1 ; and less than $105 \%$ - one deadline is set for changing the minimum wage and the minimum hourly rate: from January 1 . The amount of the minimum wage is set in such a way that the average amount of the minimum wage in a given year increases to a degree not lower than the price index forecast for a given year. Pursuant to the Act, if in the year in which negotiations take place, the amount of the minimum wage will be lower than half of the amount of the average wage, the growth rate will be additionally increased by $2 / 3$ of the forecasted real increase in gross domestic product (Article 5 of the Act).

When calculating the employee's remuneration, the following are not taken into account: jubilee bonuses, employee severance pay in connection with retirement or disability pensions, remuneration for overtime work, supplement to the remuneration for night work, and from January 12020 allowance for seniority (Article 6 of the Act). The above formal regulations condition the development of the minimum wage in Poland.

Chart 1 shows the amount of the minimum and the average wage in the economy in the years 2003-2020. Since the date of the Act, the minimum wage in Poland has increased from PLN 800 in 2003 to PLN 2,600 in 2020, i.e. by $225 \%$. In the case of average remuneration, this increase ranged from PLN 2,201.47 in 2003 to PLN 5,227 in 2020, which gives a percentage increase of $137 \%$. Therefore, the increase in the minimum wage was 88 percentage points higher than the average wage in the economy in the years studied.

The indicator that illustrates the relation between the minimum and average wages in the economy is the Kaitz index. Chart 2 presents the evolution of this indicator in Poland in the years 2003-2020. Considering the surveyed years, it can be noticed that the general tendency is increasing, i.e. when making the decision to increase the minimum wage, the state aims to reduce the gap between the minimum wage and the average wage, and thus increase the Kaitz index. In 2007, the Kaitz index recorded the lowest value in 2007 and amounted to $34.8 \%$. In the time horizon under study, the Kaitz index increased by 13.4 percentage points from $36.3 \%$ in 2003 to $49.7 \%$ in 2020 . The largest increase 
in the indicator in the years under review could be seen in 2007-2009, i.e. by 6.3 percentage points.

Decisions on raising the minimum wage in Poland are influenced by macroeconomic factors, which results from formal regulations. Chart 3 compares the dynamics of the minimum wage in the national economy to the inflation rate.

In the years studied, a positive correlation can be seen between the minimum wage in the economy and the inflation rate, which results from the legal regulations mentioned earlier. The Pearson correlation coefficient was formed in the studied years between the variables at the level of 0.41 , which indicates a positive moderate relationship between the variables. This moderate relationship results from the fact that the inflation rate is only one of the factors influencing the decision to raise the minimum wage, although decisive. Only in 2004 the difference between the minimum wage and inflation rate was negative and amounted to -0.5 percentage point, in all other years the dynamics of the minimum wage was higher than the inflation rate. The largest spread was recorded in 2008 and amounted to $16.1 \%$ (see Chart 4). On average, the increase in the minimum wage in the years under review was 5.2 percentage points higher than the inflation rate.

Chart 5 compares the dynamics of the minimum wage in the national economy to the GDP indicator. The Pearson correlation coefficient between the dynamics of the minimum wage and the GDP indicator in Poland is -0.18 , which indicates no direct relationship between the variables. In the years studied, a situation can be observed in which the GDP growth is both higher and lower than the dynamics of the minimum wage. A faster increase in the minimum wage than GDP growth is in the years 2011-2020, except for 2018, where the difference was -0.1 percentage point. However, in the years 2004-2007 Poland had a faster GDP growth than the minimum wage. Considering the entire time horizon studied, the average increase in minimum wage from GDP growth was 3.2 percentage points higher.

Chart 6 presents the spread between the dynamics of the minimum wage and the sum of the inflation and GDP index in Poland in the years 2003-2020.

Considering the surveyed years, the average increase in the minimum wage from the sum of the inflation rate and GDP growth was 1.2 percentage points higher. Of the 18 years studied, in 13 years the increase in the minimum wage was faster than the sum of the inflation and GDP indicator. The largest difference in favor of the minimum wage was recorded in 2008, i.e. at the level of 11.9 percentage points and in $2020-9.4$ percentage points.

Chart 7 shows the increase in public finance sector expenditure to the minimum wage. The Pearson correlation coefficient between the variables in the studied years was at the level of 0.46 , which indicates a positive moderate relationship between the variables. The correlated relationship between variables means that the increase in the minimum wage in Poland is accompanied by an increase in public finance sector spending. This increase in the studied years varies, 
and sometimes the minimum wage increases faster than public finance sector expenditure, and it also happens the other way around. Of course, many factors affect the increase in spending in the public finance sector, but the minimum wage in the economy is one of the important elements that determine this fact.

\section{Conclusion}

The minimum wage in the economy is an essential element in a country's economic policy. Its growth is determined by many macroeconomic and political factors. It is also important for public finances. Factors affecting changes in the minimum wage are formal and non-formal. On the basis of research carried out in Poland, a link between minimum wage and inflation was observed. There was no direct link between the GDP indicator. There is a fundamental relationship between the minimum wage and average wages in the economy. It has been shown that the minimum wage is not without significance for the impact on public expenditure in Poland.

\section{References}

Askenazy, P. (2003). Minimum wage, exports and growth. European Economic Review, 47(1), 147-164. https://doi.org/10.1016/S0014-2921(02)00187-3.

Autor, D.H., Manning, A., \& Smith, C.L. (2010). The contribution of the minimum wage to U.S. wage inequality over three decades: a reassessment. NBER Working Papers, 16533, 1-61. https://doi.org/10.3386/w16533.

Bauducco, S., \& Janiak A. (2017). The macroeconomic consequences of raising the minimum wage: capital accumulation, employment and the wage distribution. European Economic Review, 101, 57-76. https://doi.org/10.1016/j. euroecorev.2017.09.012.

Braun, C. (2019). Crime and the minimum wage. Review of Economic Dynamics, 32, 122-152. https://doi.org/10.1016/j.red.2019.02.002.

Cahuc, P., \& Zylberberg, A. (2004). Labour Economics. Mit Press.

Card, D., \& Krueger, A.B. (1994). Minimum wages and employment: a casestudy of the fast-food industry in New Jersey and Pennsylvania. American Economic Review, 84(4), 722-793.

CSO. (2021). Macroeconomic data bank. Retrieved 10.09.2021 from https:// bdm.stat.gov.pl.

Cunningham, W.(2007). Minimum wages and social policy: lessons for developing countries. Retrieved 10.09.2021 from https://openknowledge.worldbank. org/handle/10986/6760.

Goraus-Tanska, K., \& Lewandowski, P. (2016). Minimum wage violation in central and eastern Europe. IZA Discussion Paper, 10098, 1-35.

Holtemöller, O., \& Pohle, F. (2019). Employment effects of introducing a minimum wage: the case of Germany. Economic Modelling, 89, 108-121. https:// doi.org/10.1016/j.econmod.2019.10.006. 
Hungerbuhler, M., \& Lehmann, E. (2009). On the optimality of a minimum wage: new insights from optimal tax theory. Journal of Public Economics, 93(3-4), 464-481. https://doi.org/10.1016/j.jpubeco.2008.11.002.

ILO. (1970). Minimum wage fixing convention (No. 131). Retrieved 10.09.2021 from https://www.ilo.org/dyn/normlex/ en/f?p=NORMLEXPUB:12100:0::NO::P12100_ILO_CODE:C131.

ILO. (2011). Domestic workers convention (No. 189). Retrieved 10.09.2021 from https://www.ilo.org/dyn/normlex/ en/f?p=NORMLEXPUB:12100:0::NO::P12100_ILO_CODE:C189.

ILO. (2016a). Minimum wage policy guide. Retrieved 10.09.2021 from https:// www.ilo.org/wcmsp5/groups/public/ - - -ed_protect/ - - -protrav/ - - -travail/ documents/publication/wcms_508566.pdf.

ILO. (2016b). Minimum wage system. Retrieved 10.09.2021 from https:// www.ilo.org/wcmsp5/groups/public/---ed_norm/---relconf/documents/ meetingdocument/wcms_235287.pdf.

ILO. (2020). Should minimum wages apply to all employees. Retrieved 10.09.2020 from https://www.ilo.org/global/topics/wages/minimum-wages/beneficiaries/WCMS_436472/lang--en/index.htm.

Lee, D.S. (1999). Wage inequality in the united states during the 1980s: rising dispersion or falling minimum wage. The Quarterly Journal of Economics, 114(3), 977-1023. https://doi.org/10.1162/003355399556197.

MaCurdy, T. (2015). How effective is the minimum wage at supporting the poor. Journal of Political Economy, 123(2), 497-545. https://doi. org/10.1086/679626.

Marinakis, A., \& Velasco, J.J. (Eds.). (2006). Para Que Sirve el salario minimo. Organización Internacional del Trabajo.

Neumark, D., \& Wascher, W. (2006). Minimum wages and employment: a review of evidence from the new minimum wage research. University of California Irvine Working Papers, 060708, 1-151.

Saget, C. (2001). Poverty reduction and decent work in developing countries: do minimum wages help. International Labour Review, 140(3), 237-269. https://doi.org/10.1111/j.1564-913X.2001.tb00532.x.

Ustawa z dnia 10 października 2002 r. o minimalnym wynagrodzeniu za pracę [Act of 10 October 2002 on the minimum wage for work] (Dz.U. $2002 \mathrm{nr}$ 200 poz. 1679) (Poland).

Williams, N., \& Mills, J.A. (1998). Minimum wage effects by gender. Journal of Labor Research, 19, 397-414. https://doi.org/10.1007/s12122-998-1022-2.

\section{Acknowledgements}

Author contributions: author has given an approval to the final version of the article.

Funding: this research was fully funded by the Koszalin University of Technology. 


\section{Appendix}

Chart 1.

Minimum and average salary in Poland in the years 2003-2020 (in PLN)

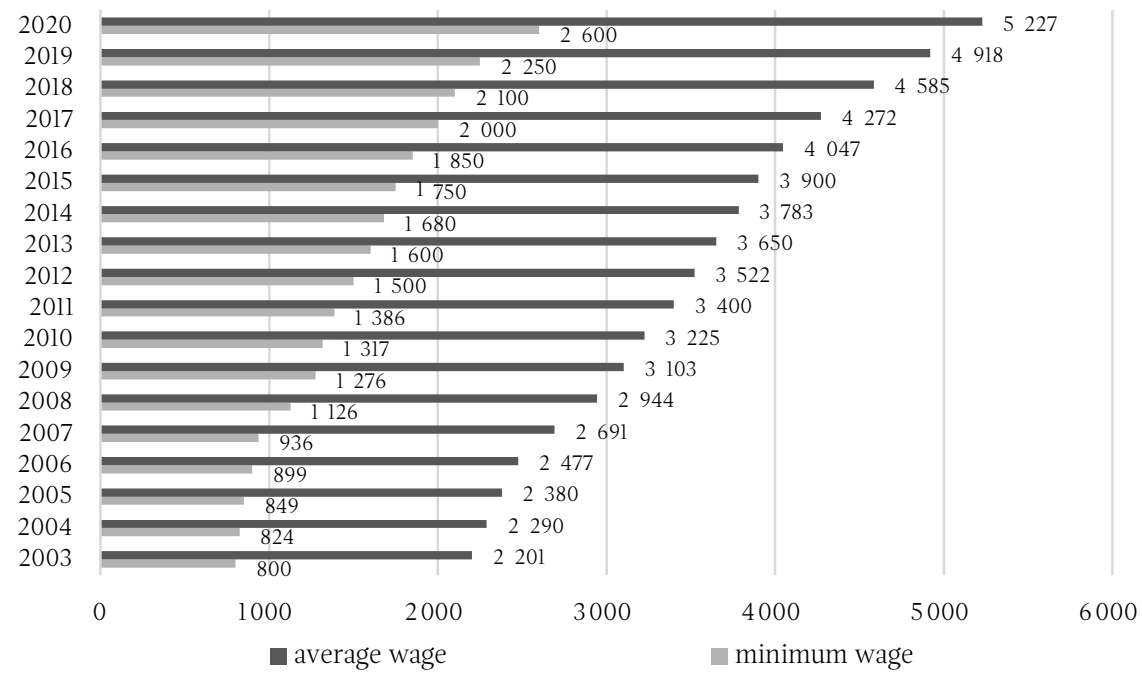

Source: Own preparation based on CSO (2021).

Chart 2.

Relationship between the minimum and average salary (Kaitz index) in Poland in the years 2003-2020 (in \%)

55

49.7

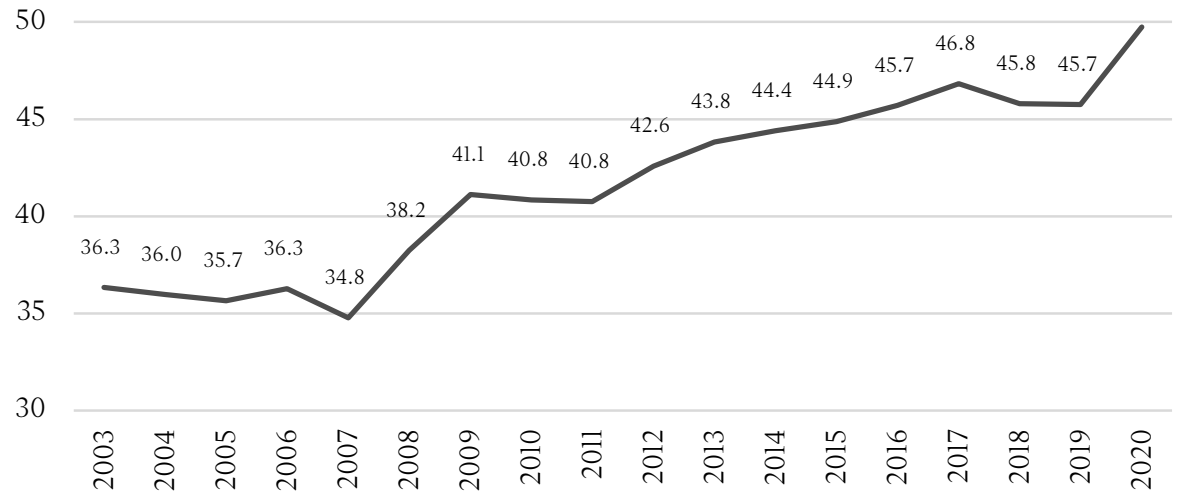

Source: Own preparation based on CSO (2021). 


\section{Chart 3.}

Dynamics of the minimum wage and inflation rate in Poland in the years 2003-2020 (in \%)

125

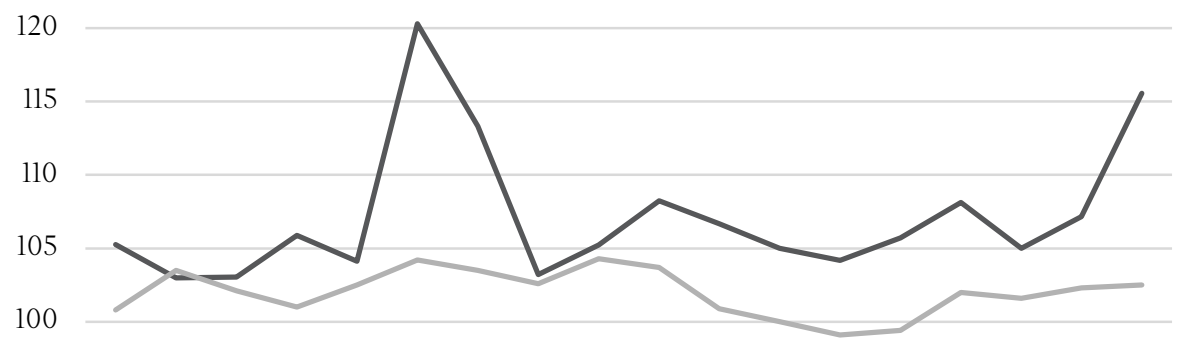

95

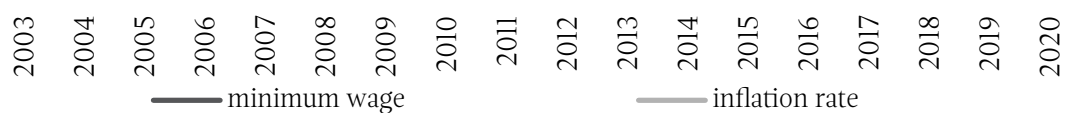

Source: Own preparation based on CSO (2021).

\section{Chart 4.}

Spread between the dynamics of the minimum wage and inflation rate in Poland in the years 2003-2020 (in \%)

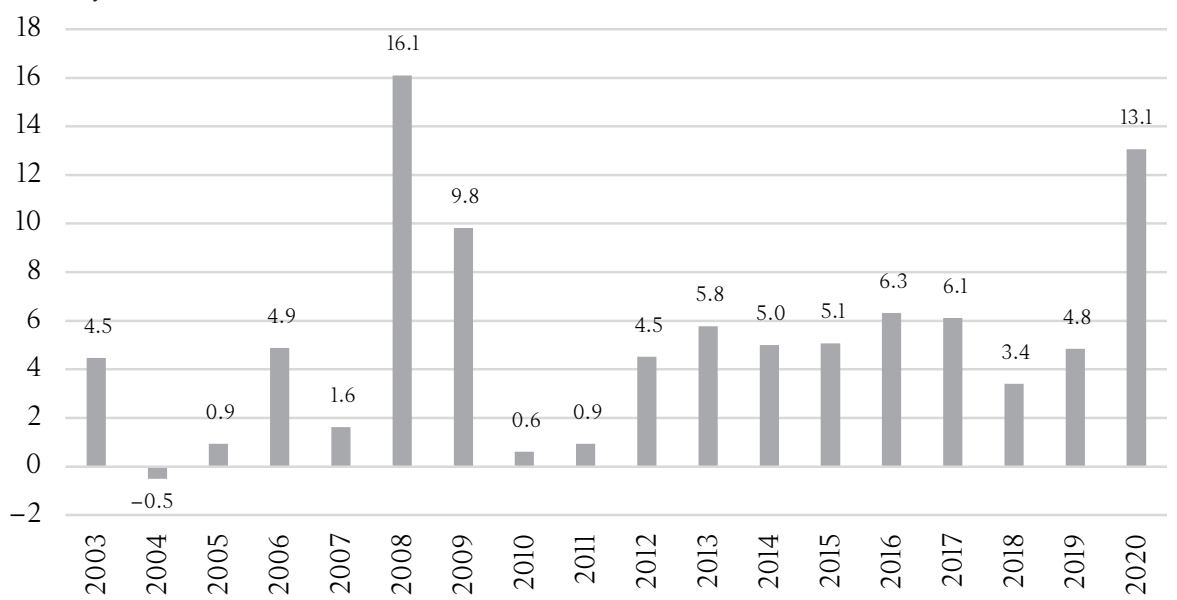

Source: Own preparation based on CSO (2021). 


\section{Chart 5.}

The spread between the dynamics of the minimum wage and the GDP indicator in Poland in the years 2003-2020 (in \%)

125

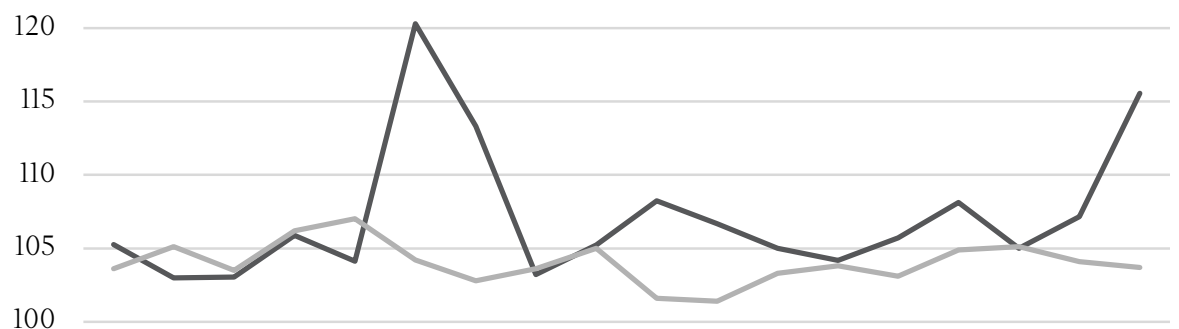

95

$$
\begin{aligned}
& \text { ڤ) } \\
& \text { minimum wage GDP indicator }
\end{aligned}
$$

Source: Own preparation based on CSO (2021).

\section{Chart 6.}

Spread between the dynamics of the minimum wage and the sum of the inflation and GDP index in Poland in the years 2003-2020 (in \%)

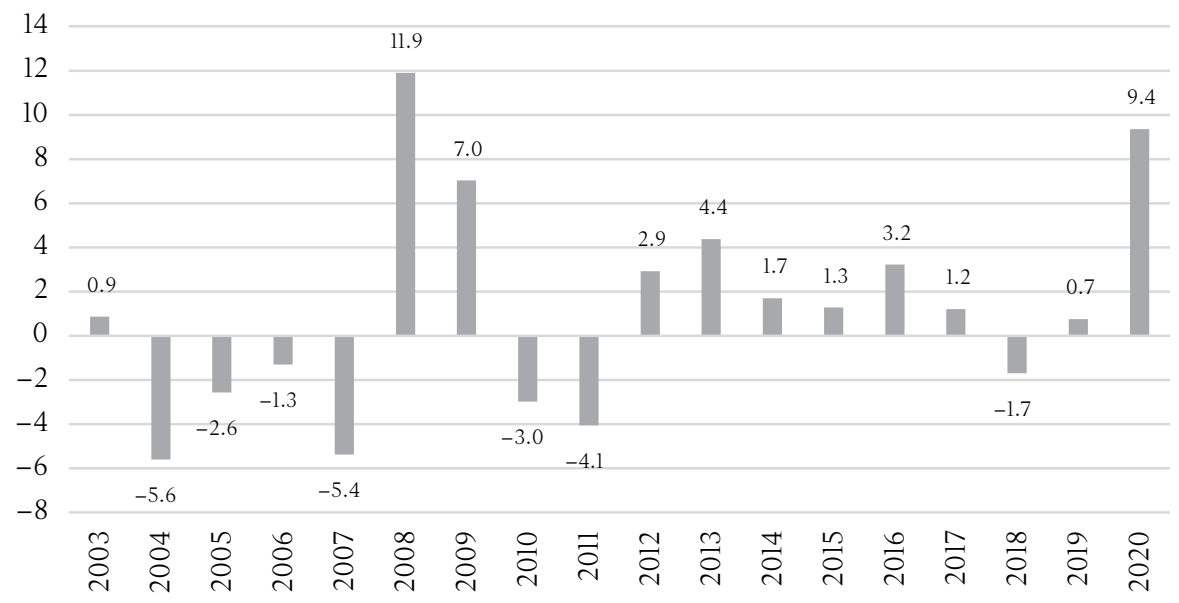

Source: Own preparation based on CSO (2021). 


\section{Chart 7.}

Spread between the dynamics of the minimum wage and the increase in expenditure of the public finance sector in Poland in the years 2003-2020 (in \%)

125

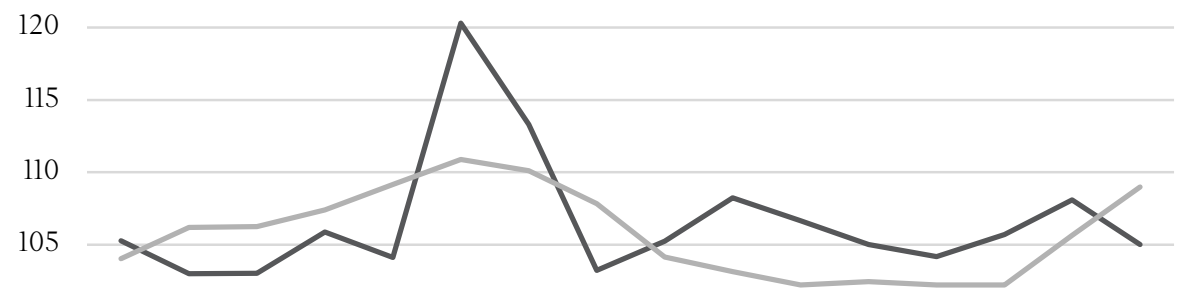

100

95

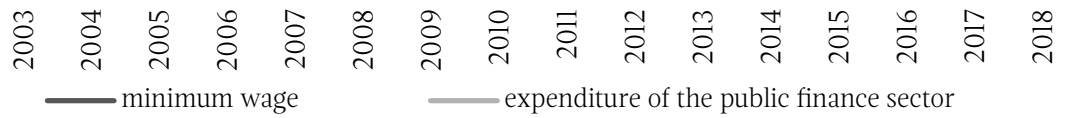

Source: Own preparation based on CSO (2021). 
